УДК 614.21:616.1/4(477)

\title{
РОЛЬ ЛІКУВАЛЬНО-ПРОФІЛАКТИЧНИХ ЗАКЛАДІВ ВСІХ ФОРМ ВЛАСНОСТІ У ПРОФІЛАКТИЦІ НЕЕПІДЕМІЧНИХ ЗАХВОРЮВАНЬ В УКРАЇНІ
}

\author{
Є. М. Гільдіна, Н. О. Теренда \\ Медичний центр «Інстинкт Сония" м. Харків \\ ДВНЗ «Тернопільський державний медичний університет \\ імені І. Я. Горбачевського МОЗ Украӥни”
}

У статті проведено огляд стану профілактичної роботи в Україні та проаналізовано роль приватних медичних закладів у наданні санітарно-просвітницької інформації серед пацієнтів комерційних медичних установ.

\section{ROLE OF THE MEDICAL AND PREVENTIVE INSTITUTION REGARDLESS OF THE FORM OF OWNERSHIP IN PREVENTION OF NON-EPIDEMIC DISEASES IN UKRAINE}

\author{
E. M. Hildina, N. O. Terenda \\ «Instynkt sontsia» Kharkiv \\ I. Horbachevsky Ternopil State Medical University
}

The article reviewed a prevention work in Ukraine and analyzed also the role of private medical institutions in providing healthcare education among patients of commercial medical institutions.

Вступ. «Майбутнє належить медицині профілактичній»- слова великого засновника наукової хірургії М. І. Пирогова, з якими важко не погодитись. Над питанням попередження захворювань ще замислювалися у Стародавньому світі, але розробка наукових основ профілактики почалася лише в XIX столітті, завдяки розвитку біологічних та медичних наук, появі таких дисциплін, як: фізіологія, гігієна, епідеміологія, дієтологія.

Переваги використання профілактичних підходів стали особливо очевидними, коли завдяки ефективним попереджувальним заходам почали рідше спостерігати випадки масових захворювань. Так, внаслідок вакцинації дітей у країнах СНД випадки захворювання на поліомієліт практично стали поодинокими. Раніше цю інфекційну хворобу спостерігали регулярними епідемічними хвилями (з 1955 до 1959 р. у Радянському Союзі щорічно виявляли від 13 до 22 тис. хворих) [2]. На даний час медицина зробила великий крок вперед як у клінічній, так іу профілактичній діяльності. 3 появою приватних медичних закладів мож-

(C) Є. М. Гільдіна, Н. О. Теренда, 2017 ливості поширення інформації щодо попередження виникнення хвороб істотно збільшилася. Проте чи користується цією можливістю саме населення та чи сприяють поширенню цієї інформації самі медичні працівники, питання залишається відкритим $[8,9]$.

Основна частина. Основними напрямками профілактичної медицини сьогодення $\epsilon$ :

- скринінгові методи діагностики соціально-значущих захворювань на стадії передхвороби і ранніх стадіях маніфестування патологічного процесу;

- своєчасна корекція порушень і ранніх стадій розвитку захворювання;

- формування знань і навичок здорового способу життя (ЗСЖ) у населення.

Якщо у першому напрямку (діагностика і вперше виявлені хвороби) державні лікувальні заклади займають провідні позиції, завдяки проведенню диспансеризації та профілактичних оглядів населення, то вже для проходження лікування сучасні українці все частіше надають перевагу приватним медичним установам. За статистикою кожен третій громадянин України хоч раз звертався за медичною допомогою 
у комерційні заклади (вік респондентів від 18 до 35 років). Таким чином, приватні лікувально-профілактичні заклади знімають навантаження з державних лікарень та поліклінік, адже на сьогодні понад 10 \% населення України постійно обслуговуються у приватних медичних кабінетах або приватних медичних центрах [4].

В Основах законодавства України про охорону здоров'я зазначається, що «Суспільство і держава відповідальні перед сучасним і майбутніми поколіннями за рівень здоров'я і збереження генофонду народу України, забезпечують пріоритетність охорони здоров'я в діяльності держави, поліпшення умов праці, навчання, побуту і відпочинку населення, розв'язання екологічних проблем, вдосконалення медичної допомоги і запровадження здорового способу життя» [6].

Важливими захворюваннями, які визначають рівень захворюваності та смертності населення України, $\epsilon$ неінфекційні захворювання (НІЗ). Сюди передусім належать хвороби серцево-судинної системи, онкологічні захворювання. Численні дослідження вказують, що НІЗ становлять найбільшу загрозу для здоров'я населення як в Європейському регіоні ВООЗ, так і в країнах СНД, зокрема, і в Україні $[5,11]$. В Ашхабадській декларації з профілактики та боротьби з неінфекційними захворюваннями, яка була затверджена державами-членами у грудні 2013 р., визнано зростання значущості HІ3, які перешкоджають соціальному та економічному розвитку всіх країн [1].

Боротьба з основними факторами ризику розвитку НІЗ (тютюнокуріння, вживання алкоголю, незбалансований раціон харчування, хронічний стрес, недостатня фізична активність, надмірна маса тіла, артеріальна гіпертензія і токсичний вплив ксенобіотиків) може попередити їх виникнення або уповільнити прогресування аж до найпізніших етапів життя людини. Правильний профілактичний підхід до вирішення цієї проблеми дозволить істотно поліпшити здоров'я населення при відносно низьких затратах.

У вирішенні цих питань потрібна взаємодія держави, громадянського суспільства, працівників лікувально-профілактичних закладів і самих громадян [3]. Позитивним є досвід зарубіжних країн у боротьбі з факторами ризику. Такі програми, як «Здоров'я серця» (США, штат Міннесота), «Серцебиття Лімбурга» (провінція Лімбург Маастрихтського регіону Нідерландів), «Північна Карелія» (Фінляндія) довели ефективність профілактичної роботи в боротьбі з факторами ри- зику та покращенні здоров'я населення. Як результат такої діяльності - здорове населення та неухильно зростаюча кількість довгожителів. Для порівняння: середня тривалість життя в Україні становить 70,4 року, а в Європі цей показник складає на 10 років більше, і з кожним десятиріччям прогресує (середня тривалість життя населення Європи становить 81,2).

На жаль, в Україні поки що серед населення поширене негативне ставлення до турботи за стан свого здоров'я. За даними А. В. Коваленко, В. І. Клименко, лише 41,8 \% респондентів при погіршенні стану свого здоров'я звертаються до медичного закладу, 17,6 \% йдуть до аптеки і самостійно приймають ліки симптоматично, 14,0 \% лікуються народними засобами, займаючись самолікуванням, 14,8 \% взагалі нічого не роблять і чекають «поки все минеться», 7,5 \% йдуть до храму і ще 4,4 \% шукають поради в інтернеті [7].

Для проведення профілактичної роботи доцільно використовувати можливості всіх медичних закладів України незалежно від їх юридичного статусу. 3 початку 90-х років в Україні починають з'являтися перші приватні клініки, які пропонували населенню платні медичні послуги. Вже під кінець 2010 р. була сформована структура таких приватних медичних закладів, в яких основну масу (74,2 \%) становили установи і заклади, що мали в своєму штаті 10-20 працівників. Потужних клінік із чисельністю працівників понад одну тисячу було лише 1,3 \% [10]. У приватних медичних закладах після обстеження і формування основного діагнозу лікар або медична сестра обов'язково дає рекомендації щодо корекції та модифікації способу життя, радить виконувати лікувальні фізичні вправи в домашніх умовах та стежити за раціоном харчування, у разі необхідності призначає лікувальну дієту, оповіщає про проведення сезонної вакцинації. При таких закладах починають функціонувати так звані «Клуби здоров'я», де медичні працівники проводять семінари у вигляді інтерактивних тренінгів на різноманітні теми стосовно здоров'я та здорового способу життя, інформують тільки про актуальне на сьогодні, надають усі необхідні витратні матеріали. Єдиним мінусом таких занять $€$ їх комерційна основа, тому дозволити їх може собі не кожен і не всі бачать у цьому потребу. В людей, які мешкають на пострадянському просторі склалося згубне мислення: вони готові віддавати гроші за розваги, брендовий одяг, мандрівки, за усе, крім найголовнішого - свого здоров'я. І тут знову питання постає про пропаганду профілактичної роботи на державному рівні. 
Висновок. Проведення профілактичної роботи серед населення України залишається недостатнім і потребує негайної реорганізації на державному рівні

\section{СПИСОК ЛІТЕРАТУРИ}

1. Ашхабадская декларация по профилактике и борьбе с неинфекционными заболеваниями в контексте положений политики Здоровье-2020 [Электронный ресурс] / Европейская министерская конференция ВОЗ по профилактике и борьбе с неинфекционными заболеваниями в контексте положений политики Здоровье-2020 (Ашхабад, 3-4 дек. 2013 г.) - Режим доступа : http://www. euro.who.int/ru/media-centre/events/events/2013/12/ ashgabat-conference-on-noncommunicable-diseases/aboutthe-conference

2. Бондарев Л. С. Можно ли считать полиомиелит ликвидированной болезнью / Л. С. Бондарев. - Донецк, 2010. - 95 с.

3. Взаємодія «держава-громада» заради здоров'я: зарубіжний досвід боротьби з неінфекційними захворюваннями / Н. О. Рингач, О. М. Дзюба, О. Р. Ситенко, А. О. Керецман // Вісн. соц. гігієни та орг. охорони здоров'я України. - 2015. - № 1. - С. 35-41.

4. Дудка В. В. Переваги приватної медицини та вигоди держави у підтримці розвитку приватного сектора системи охорони здоров'я України (до проблеми державного регулювання здоровоохоронної сфери) [Електронний ресурс] / В. В. Дудка // Державне управління: удосконалення та розвиток. - 2012. - № 1. - Режим доступу : http:// www.dy.nayka.com.ua/?op $=1 \& z=381$

5. Дячук Д. Д. Щодо захворюваності дорослого населення України на неінфекційні хвороби / Д. Д. Дячук // Вісн. із залученням лікувально-профілактичних закладів всіх форм власності.

соц. гігієни та орг. охорони здоров'я України. - 2011. № 1. - С. 19-23.

6. Закон України від 19 листопада 1992 року № 2801-XII «Основи законодавства України про охорону здоров'я» [Електронний ресурс]. - Режим доступу : http://zakon. kadrovik01.com.ua/regulations/8186/8191/460882/

7. Коваленко А. В. Медико-організаційні недоліки профілактики хвороб системи кровообігу в Україні та шляхи їх подолання / А. В. Коваленко, В.І.Клименко // Вісн. соц. гігієни та орг. охорони здоров'я України. - 2014. № 4. - С. 12-16.

8. Материалы для подготовки и квалификационной аттестации по специальности «Гражданское здоровье и охрана здоровья» : учебное пособие / под ред. В. С. Лучкевича и И. В. Полякова. - Санкт-Петербург, 2005. - 153 с.

9. Орлова Г. Г. Навчальний посібник з профілактичної медицини / Г. Г. Орлова. - 2003. - 123 с.

10. Поживілова О. В. Функціонування приватних закладів у сфері охорони здоров'я [Електронний ресурс] / О. В. Поживілова. - Режим доступу : www.dridu.dp.ua/ zbirnik/2011-01(5)/11 povsoz.pdf

11. Ritsatakis A. Gaining health. Analysis of policy development in European countries for tackling noncommunicable diseases / A. Ritsatakis, P. Makara Copenhagen, 2011. - 265 p. [Electronic resource]. - Access mode : http://www.euro.who.int/__data/assets/pdf_ file/0018/105318/e92828.pdf 